\title{
Receiver function images of the Hellenic subduction zone and comparison to microseismicity
}

\author{
F. Sodoudi ${ }^{1}$, A. Brüstle ${ }^{3}$, T. Meier ${ }^{4}$, R. Kind ${ }^{1,2}$, W. Friederich ${ }^{3}$, and EGELADOS working group \\ ${ }^{1}$ Helmholtz Centre Potsdam, GFZ German Research Centre for Geosciences, Telegrafenberg, 14473 Potsdam, Germany \\ ${ }^{2}$ Department of Earth Sciences, Freie Universität Berlin, Malteserstr. 74-100, 12249 Berlin, Germany \\ ${ }^{3}$ Faculty of Geosciences, Ruhr-Universität Bochum, Universitätsstr. 150, 44801 Bochum, Germany \\ ${ }^{4}$ Institute of Geosciences, Christian-Albrechts Universität zu Kiel, Otto-Hahn-Platz 1, 24118 Kiel, Germany
}

Correspondence to: F. Sodoudi (foroug@gfz-potsdam.de)

Received: 22 March 2013 - Published in Solid Earth Discuss.: 16 April 2013

Revised: 29 November 2014 - Accepted: 28 December 2014 - Published: 4 February 2015

\begin{abstract}
New combined P receiver functions and seismicity data obtained from the EGELADOS network employing 65 seismological stations within the Aegean constrained new information on the geometry of the Hellenic subduction zone. The dense network and large data set enabled us to estimate the Moho depth of the continental Aegean plate across the whole area. Presence of a negative contrast at the Moho boundary indicating the serpentinized mantle wedge above the subducting African plate was seen along the entire forearc. Furthermore, low seismicity was observed within the serpentinized mantle wedge. We found a relatively thick continental crust (30-43 km) with a maximum thickness of about $48 \mathrm{~km}$ beneath the Peloponnese Peninsula, whereas a thinner crust of about $27-30 \mathrm{~km}$ was observed beneath western Turkey. The crust of the overriding plate is thinning beneath the southern and central Aegean and reaches $23-27 \mathrm{~km}$. Unusual low Vp / Vs ratios were estimated beneath the central Aegean, which most likely represent indications on the pronounced felsic character of the extended continental Aegean crust. Moreover, $\mathrm{P}$ receiver functions imaged the subducted African Moho as a strong converted phase down to a depth of about $100 \mathrm{~km}$. However, the converted Moho phase appears to be weak for the deeper parts of the African plate suggesting nearly complete phase transitions of crustal material into denser phases. We show the subducting African crust along eight profiles covering the whole southern and central Aegean. Seismicity of the western Hellenic subduction zone was taken from the relocated EHB-ISC catalogue, whereas for the eastern Hellenic subduction zone, we used the catalogues of manually picked hypocentre locations of
\end{abstract}

temporary networks within the Aegean. Accurate hypocentre locations reveal a significant change in the dip angle of the Wadati-Benioff zone (WBZ) from west $\left(\sim 25^{\circ}\right)$ to the eastern part $\left(\sim 35^{\circ}\right)$ of the Hellenic subduction zone. Furthermore, a zone of high deformation can be characterized by a vertical offset of about $40 \mathrm{~km}$ of the WBZ beneath the eastern Cretan Sea. This deformation zone may separate a shallower $\mathrm{N}$-ward dipping slab in the west from a steeper $\mathrm{NW}$-ward dipping slab in the east. In contrast to hypocentre locations, we found very weak evidence for the presence of the slab at larger depths in the $\mathrm{P}$ receiver functions, which may result from the strong appearance of the Moho multiples as well as eclogitization of the oceanic crust. The presence of the top of a strong low-velocity zone at about $60 \mathrm{~km}$ depth in the central Aegean may be related to the asthenosphere below the Aegean continental lithosphere and above the subducting slab. Thus, the Aegean mantle lithosphere seems to be $30-40 \mathrm{~km}$ thick, which means that its thickness increased again since the removal of the mantle lithosphere about 15 to 35 Ma ago.

\section{Introduction}

The tectonics of the Hellenic subduction zone has been controlled since late Cretaceous by the convergence between Africa and Eurasia, the subduction of African oceanic lithosphere beneath the Aegean lithosphere and the accretion of Africa-derived terranes to Eurasia (e.g. Dercourt et al., 1986; Gealey, 1988; Stampfli and Borel, 2004). The recent 
kinematics of the Aegean is characterized by a counterclockwise rotation of the Aegean and the Anatolian plates and internal extension of the plates (e.g. McKenzie, 1972, 1978; LePichon et al., 1995; Cocard et al., 1999; Kahle et al., 1999; McClusky et al., 2000). Subduction of African oceanic lithosphere along the Hellenic arc and its associated rollback is supposed to be the cause of the extension and might contribute to the rotation of the Anatolian-Aegean plate (e.g. LePichon et al., 1995; McClusky et al., 2000). From late Miocene time onward, extensional basins developed in the entire Aegean (e.g. Mascle and Martin, 1990; Brun and Sokoutis, 2010), combined with the propagation of the North Anatolian fault into the Aegean region since about ca. $5 \mathrm{Ma}$ (Armijo et al., 1996; Faccenna et al., 2006). Recent studies showed that stretching of the Aegean lithosphere took place in a distinctly episodic fashion, not in a manner that can be described as continuous or progressive (e.g. Forster and Lister, 2009). However, the style of the deformation that accommodates the extension is disputed. Recent seismic anisotropy analysis found evidence for a highly 3-D deformation pattern, strong Miocene extension of the lower crust in the southern Aegean associated with the formation of metamorphic core complexes and significant recent deformation of the entire lithosphere in the northern Aegean (Endrun et al., 2011).

High seismic activity occurs along the Hellenic arc (e.g. Papazachos and Comnikakis, 1971; Hatzfeld and Martin, 1992; Knapmeyer, 1999; Papazachos et al., 2000). The Benioff zone steepens from the western towards the eastern part of the Hellenic subduction zone and reaches depths of about $100-180 \mathrm{~km}$ beneath the volcanic arc, where it roughly terminates. Thus, imaging the subducting African plate towards greater depths is challenging and may be restricted to seismic tomography or studies of converted or scattered waves. In general, seismic tomography provided relatively unsharp images of the Hellenic subduction zone (e.g. Spakman et al., 1988, 1993; Papazachos and Nolet, 1997; Bijwaard et al., 1998; Piromallo and Morelli, 2003; Schmid et al., 2004; Chang et al., 2010; Biryol et al., 2011). Studies of converted or scattered waves in the Aegean were mainly obtained from small networks mostly covering the western part of the Hellenic arc (e.g. Suckale et al., 2009; Gesret et al., 2011; Pearce et al., 2012).

Temporal and spatial variations in convergence rate are exhibited along the Hellenic subduction zone (e.g. McClusky et al., 2000). Based on GPS measurements (McClusky et al., 2000; Reilinger et al., 2010; DeMets et al., 1990), subduction becomes increasingly oblique from west to east. In the western part, the vectors of motion are oriented normal to the continental margin, whereas towards the east, in the area of Rhodes (stations RHON, RHOS, Fig. 1), the angle between the motion vector and the active margin decreases causing left-lateral movement between forearc slivers. Özbakir et al. (2013) conducted a detailed analysis on the correspondence of model shear zone structures to observations and

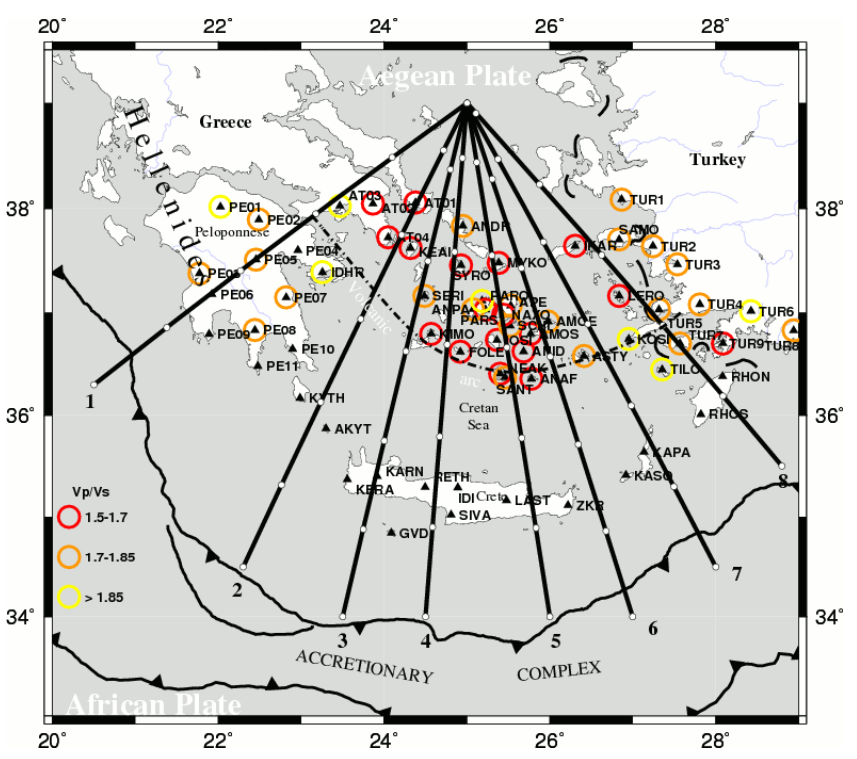

Figure 1. Distribution of the EGELADOS stations used for receiver function analysis (black triangles). The southern deformation front of the Hellenic subduction zone and the border between the central and the inner units of the Mediterranean Ridge are shown with black solid lines with triangles (simplified after Chamot-Rooke et al., 2005). Dash-dotted line denotes location of the volcanic arc. Black thick lines indicate the positions of eight $\mathrm{S}-\mathrm{N}$ trending profiles used for $\mathrm{P}$ receiver functions. Small white circles on the profiles lines mark $100 \mathrm{~km}$ distance interval. Estimated values of Vp / Vs ratio are marked with coloured circles.

proposed that the trench perpendicular convergence in the eastern Hellenic arc is taken up by a shear zone and a fold and thrust belt in the Rhodes Basin. Due to the lack of clear geophysical images of the slab in the eastern Hellenic subduction zone Özbakir et al. (2013) question the existence of a NW dipping slab in the region of Rhodes.

The crustal structure of the Hellenic subduction zone has been intensively studied by different reflection, refraction and receiver function studies (e.g. Makris and Vees, 1977; Makris, 1978; Hirn et al., 1996; Mascle and Chaumillon, 1998; Knapmeyer and Harjes, 2000; Bohnhoff et al., 2001; Li et al., 2003; Endrun et al., 2004; Sodoudi et al., 2006). At greater depths, global and regional P-wave tomographies show that the Hellenic subduction zone coincides with high seismic velocity anomalies that extend through the upper mantle into the lower mantle (e.g. Spakman et al., 1988, 1993; Papazachos and Nolet, 1997; Bijwaard et al., 1998; Piromallo and Morelli, 2003; Schmid et al., 2004; Chang et al., 2010; Biryol et al., 2011). Furthermore, they imaged a not completely amphitheatrical geometry for the subducted African slab and showed a gradual increase in the slope of the Hellenic slab from west to east and toward the larger depths of the slab. Based on the model proposed by Papazachos and Nolet (1997), the western part of the slab is much larger than its eastern part. Moreover, the western part has an 
approximately constant NW-SE strike, forming at approximately $200 \mathrm{~km}$ depth a right angle with the eastern part. These results together with the distribution of intermediatedepth seismicity (e.g. Papazachos et al., 2000) implied a segmentation of the subducting African slab in the Hellenic subduction zone.

The geometry of the Hellenic subduction zone has been also studied by other geophysical methods, but none of them has been resolved the subducting slab at depths larger than about $160 \mathrm{~km}$ (e.g. Makris and Vees, 1977; Makris, 1978; Knapmeyer and Harjes, 2000; Bohnhoff et al., 2001; Li et al., 2003; Endrun et al., 2004, 2008; Meier et al., 2004; Tirel et al., 2004; Snopek and Casten, 2006). Recently, receiver function studies have obtained new constraints on the nature of the subducting African plate mainly in the western Hellenic arc (e.g. Sodoudi et al., 2006; Suckale et al., 2009; Gesret et al., 2011; Pearce et al., 2012). The base of the subducting African lithosphere has been demonstrated down to a depth of about $225 \mathrm{~km}$ beneath the volcanic arc using converted Sto-P waves (e.g. Sodoudi et al., 2006).

The establishment of the temporary, broadband seismic network of EGELADOS (Exploring the Geodynamics of Subducted Lithosphere using an Amphibian Deployment Of Seismographs) within the CRC 526 "Rheology of the Earth" founded by the Deutsche Forschungsgemeinschaft covering the entire Hellenic subduction zone from the Peloponnese in the west to the western Turkish coast in the east, was carried out by the Ruhr-University Bochum in collaboration with partners at the Aristoteles University of Thessaloniki, the National Observatory Athens, the Technical University of Crete, the Istanbul Technical University, the GFZ Potsdam and the University of Hamburg (Fig. 1). Deploying more than 80 temporary on-shore and off-shore stations provides a unique opportunity to obtain high-resolution seismic images of the structure and seismicity of the subducted plate and the overriding Aegean plate.

In the present study, we employ the $\mathrm{P}$ receiver function technique to the temporary land stations and the permanent GEOFON stations. Dense seismic sampling obtained from these stations enables us to create a high-resolution image of the Aegean plate and the descending African plate in the southern and central Aegean. We combine our results with hypocentre locations of the EHB-ISC catalogue (Engdahl et al., 1998) for the western Hellenic subduction zone and with new accurate hypocentre locations recorded by the temporary CYCNET and EGELADOS networks (Brüstle, 2012; Brüstle et al., 2014) as well as hypocentre locations by the temporary LIBNET network (Becker et al., 2009) for the eastern Hellenic subduction zone and particularly discuss the correlation of $\mathrm{P}$ receiver function images and the hypocentre distribution.

\section{Data and methodology}

The EGELADOS network consists of 56 on-shore stations deployed on the Greek mainland, on most of the southern Aegean islands and in western Turkey from October 2005 to April 2007. In addition, 24 off-shore stations were deployed in the region. Forty-five of the temporary on-shore stations and all off-shore stations were equipped by the German amphibian seismograph pool (DEPAS). The remaining temporary stations were provided by Ruhr-University Bochum. Additionally, 22 permanent on-shore stations of the Global Seismic Network GEOFON (Geoforschungszentrum Potsdam, Germany), the Hellenic Broadband Seismic Network HL (National Observatory Athens NOA, Greece), and the Mediterranean Network MedNet (Instituto Nazionale di Geofisica e Vulcanologia INGV, Italy) were also included to complete the temporary network. We used at least 1.5 years of teleseismic data recorded at 65 on-shore stations (56 temporary and 9 permanent GEOFON stations) to calculate the $P$ receiver functions (Fig. 1). All available events with a magnitude $(\mathrm{mb})$ larger than 5.5 and at a distance of $30^{\circ}-95^{\circ}$ were analysed. They also provided sufficient azimuthal coverage $\left(0^{\circ}-360^{\circ}\right)$. More than 11 years of data were available for the permanent GEOFON stations for the $\mathrm{P}$ receiver function analysis. We computed $\mathrm{P}$ receiver functions (e.g. Langston, 1977; Owens et al., 1984; Kind and Vinnik, 1988; Yuan et al., 1997; Kosarev et al., 1999) for all stations. The processing steps used in this paper are similar to those described by Sodoudi et al. (2006).

To image the seismicity of the Hellenic subduction zone, about 8200 hypocentre locations with a location uncertainty of less than $20 \mathrm{~km}$ were selected from various catalogues. Seismicity of the western Hellenic subduction zone (lat $<25^{\circ}$, profiles $1-4$ in Fig. 1) was taken from the relocated EHB-ISC catalogue 1960-2007 (Engdahl et al., 1998). Seismicity of the eastern Hellenic subduction zone (lat $>25^{\circ}$, profiles 4-8 in Fig. 1) was taken from catalogues of manually picked hypocentre locations of temporary networks. This data set consists of about 3000 hypocentre locations (Brüstle, 2012; Brüstle et al., 2014) observed by the temporary EGELADOS network, of about 4000 relocated hypocentre locations (Brüstle et al., 2014) obtained by the temporary CYCNET network covering the central subduction zone from 2002-2004 (Bohnhoff et al., 2004, 2006), and of about 2000 hypocentre locations of the temporary LIBNET network (Becker et al., 2009) covering the forearc Southeast of Crete from 2003-2004.

\section{Observations}

Earthquake catalogues used in this work show that shallow seismicity within the Aegean plate is observed down to about $20 \mathrm{~km}$, predominantly along extensional structures in the thinned brittle Aegean crust. In the regions of transtensional 
structures in the forearc that have been identified as nearly vertical margins of forearc slivers the seismicity extends down to the subduction interface (Meier et al., 2007; Becker et al., 2009; Brüstle et al., 2014). The seismicity of the plate contact is only incompletely recorded due to the limited station coverage by permanent and temporary networks. In this study, only south of eastern Crete is the plate contact resolved in detail by the dense temporary on-shore/off-shore LIBNET network (Becker et al., 2009). Other temporary networks covering western and central Crete located the seismogenic zone of the plate interface south of Crete with a lateral extent of $40-100 \mathrm{~km}$ and at $20-40 \mathrm{~km}$ depth (Meier et al., 2004). Another dense temporary network deployed in the region of the Ionian islands at the northwestern margin of the subduction zone located the seismogenic plate interface west and beneath of Cephalonia, with an lateral extension of about $60-70 \mathrm{~km}$, dipping from about $10 \mathrm{~km}$ depth in the west to about $20 \mathrm{~km}$ in the east (Sachpazi et al., 2000).

Stacked traces of $\mathrm{P}$ receiver functions (PRFs) of 65 EGELADOS on-shore stations are shown in Fig. 2. They are filtered with a low-pass filter of $1 \mathrm{~s}$. At all stations, except those located in the forearc of the subduction zone (the area trapped between the Hellenic trench and the volcanic arc, see Fig. 1), we clearly observed a positive P-to-S conversion in the time interval from 2.5 to $6 \mathrm{~s}$ delay time, which stem from the Moho of the continental Aegean plate. Multiple converted phases from the Moho boundary can be also observed beneath some stations (Fig. 2). The converted Moho phase is strongly imaged beneath the stations located relatively far from the Hellenic trench (see Fig. 1). At the stations located in the forearc of the subduction zone (marked Forearc in Fig. 2), the converted Moho phase with positive polarity disappeared and instead a negative phase is seen. Such a reversal of sign for the Moho conversion has been previously observed beneath the Cascadia, Hellenic subduction zone and Central Andes (e.g. Knapmeyer and Harjes, 2000; Bostock et al., 2002; Li et al., 2003; Endrun et al., 2004; Sodoudi et al., 2006, 2011).

To have a clear image of the subducted African Moho (hereafter referred to as slab), we separately show the stacked PRFs obtained from the western and eastern parts of the Aegean. For the western part we took stations along profiles 1-3 and for the eastern part those along profiles 4-7 (see Fig. 1). Figure 3 illustrates the stacked PRF traces obtained from these two parts. The PRFs are filtered with a low pass of $3 \mathrm{~s}$ and sorted by the relative distance of the stations from the Hellenic trench. Moreover, we show them in a larger time window compared to that in Fig. 2. As Fig. 3 shows, the most pronounced conversions correspond to the slab. This phase is clearly shown at times ranging from $6 \mathrm{~s}$ beneath the forearc region to about $11 \mathrm{~s}$ beneath Peloponnese (station PE04) in the western Aegean (Fig. 3a), whereas it can be followed from 5 to about $8 \mathrm{~s}$ beneath the forearc area (station KAPA) in the eastern Aegean (Fig. 3b). Further north, the continuation of the slab phase is not more clear. Instead, significant con-

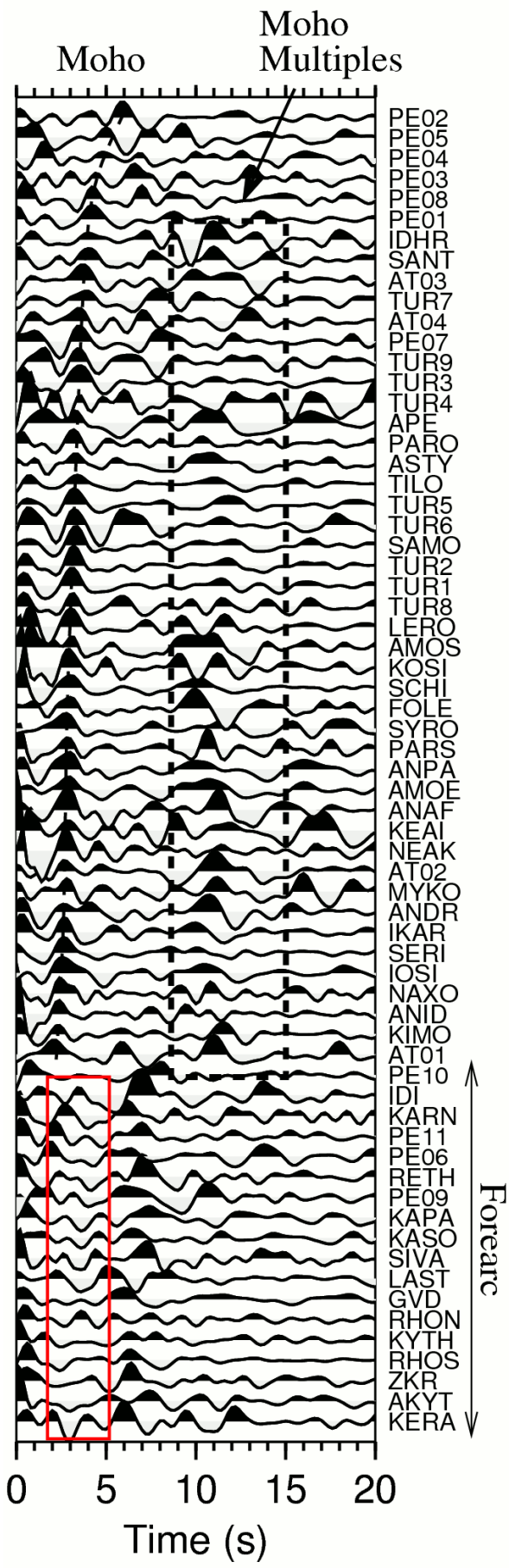

Figure 2. Stacked PRFs of 65 EGELADOS stations. Seismic traces are moveout corrected for a reference distance of $67^{\circ}$ before summation. Stations are sorted (except stations in the forearc) according to the arrival time of the Aegean Moho phase from 2.3 to $6 \mathrm{~s}$ (black dashed line). Data are filtered using a 1s low-pass filter. Few positive P-to-S conversions from the Aegean Moho can be seen beneath the forearc stations (red box). Arrival time window of the Moho multiples is shown with black dashed box. 


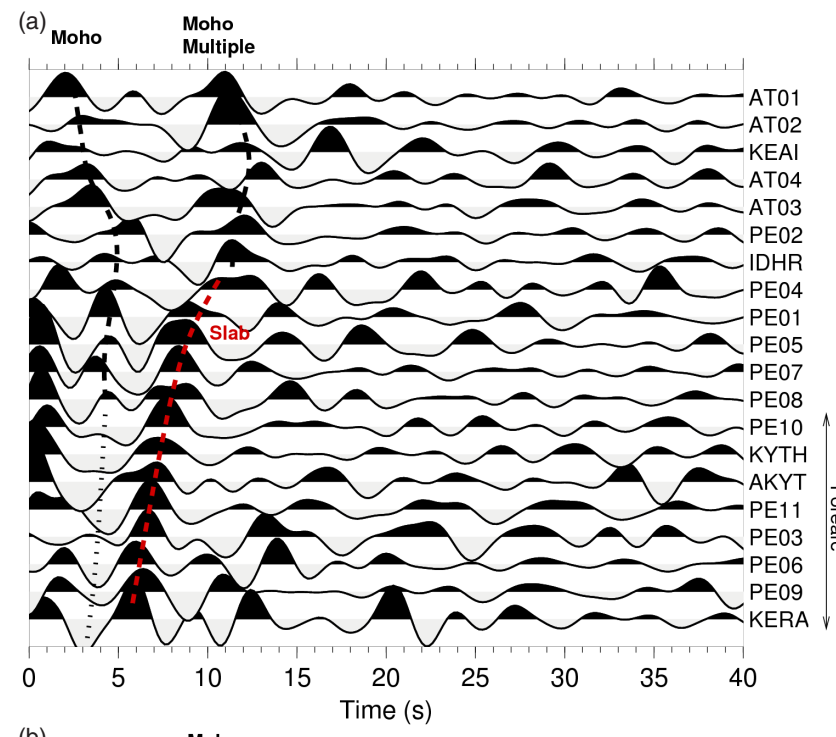

\section{Results}

\subsection{Aegean Moho depth}

\subsubsection{Zhu and Kanamori approach}

Clear arrivals of the Moho conversions (Fig. 2) allowed a first-order estimation of the crustal thickness beneath the whole region except the forearc area due to the absence of positive Moho conversions. For stations with relatively clear multiples we estimate the crustal thickness and $\mathrm{Vp} / \mathrm{Vs}$ ratio from the H-k stacking technique (Zhu and Kanamori, 2000), which assumes a flat homogeneous layered structure beneath the station. The receiver functions are stacked at each station. We considered different weights $(0.6,0.3$ and 0.2$)$ for the three converted phases (Ps, Ppps and Psps + Ppss). The maximum amplitude of stacked traces appear where the three phases add constructively. We used an average crustal velocity $(\mathrm{Vp})$ of $6.2 \mathrm{~km} \mathrm{~s}^{-1}$ for the depth estimation and performed this analysis for all stations. Our results are listed in Table 1 and are shown in Fig. 1. Figure 4 shows the estimates of crustal thickness and $\mathrm{Vp} / \mathrm{Vs}$ ratio for eight selected stations. The theoretical arrival times of Ps, Ppps and Psps + Ppss predicted by the estimated crustal thickness and $\mathrm{Vp} / \mathrm{Vs}$ ratio (thin red lines) mostly coincide with those of the observed converted phases.

Our analysis shows that, given a range of probable values for average crustal velocity $(\mathrm{Vp})$, crustal thickness can change by nearly $4 \mathrm{~km}$, whereas the $\mathrm{Vp} / \mathrm{Vs}$ ratio can vary by $0.06-0.16$. Large uncertainties are probably due to the absence of multiple energy, significant component of slab interference or the deviation of the structure beneath the station of a locally flat and homogeneous layered structure. In general, we found $\mathrm{Vp} / \mathrm{Vs}$ ratios varying between 1.7 and 1.8 for the stations located in the Peloponnese Peninsula and western Turkey (see Fig. 1), which are in good agreement with those reported by the previous PRF studies (e.g. Karabulut et al., 2013; Vanacore et al., 2013). In contrast, unusually low $\mathrm{Vp} / \mathrm{Vs}$ ratios in the range of 1.5-1.7 were found for the majority of stations located in the central Aegean Sea and close to the volcanic arc. Anomalous Vp / Vs ratios are frequently shown in subduction zones (e.g. Zandt et al., 1994; Wagner et al., 2005; Zheng and Lay, 2006) and provided useful information on the composition of crustal rocks. Although presence of high values of $\mathrm{Vp} / \mathrm{Vs}$ ratio in subduction zones can be associated with rocks of more mafic composition, low values of $\mathrm{Vp} / \mathrm{Vs}$ ratio may reveal felsic crustal composition and high upper-crustal temperatures, which correspond to rocks which contain large amounts of silica. 

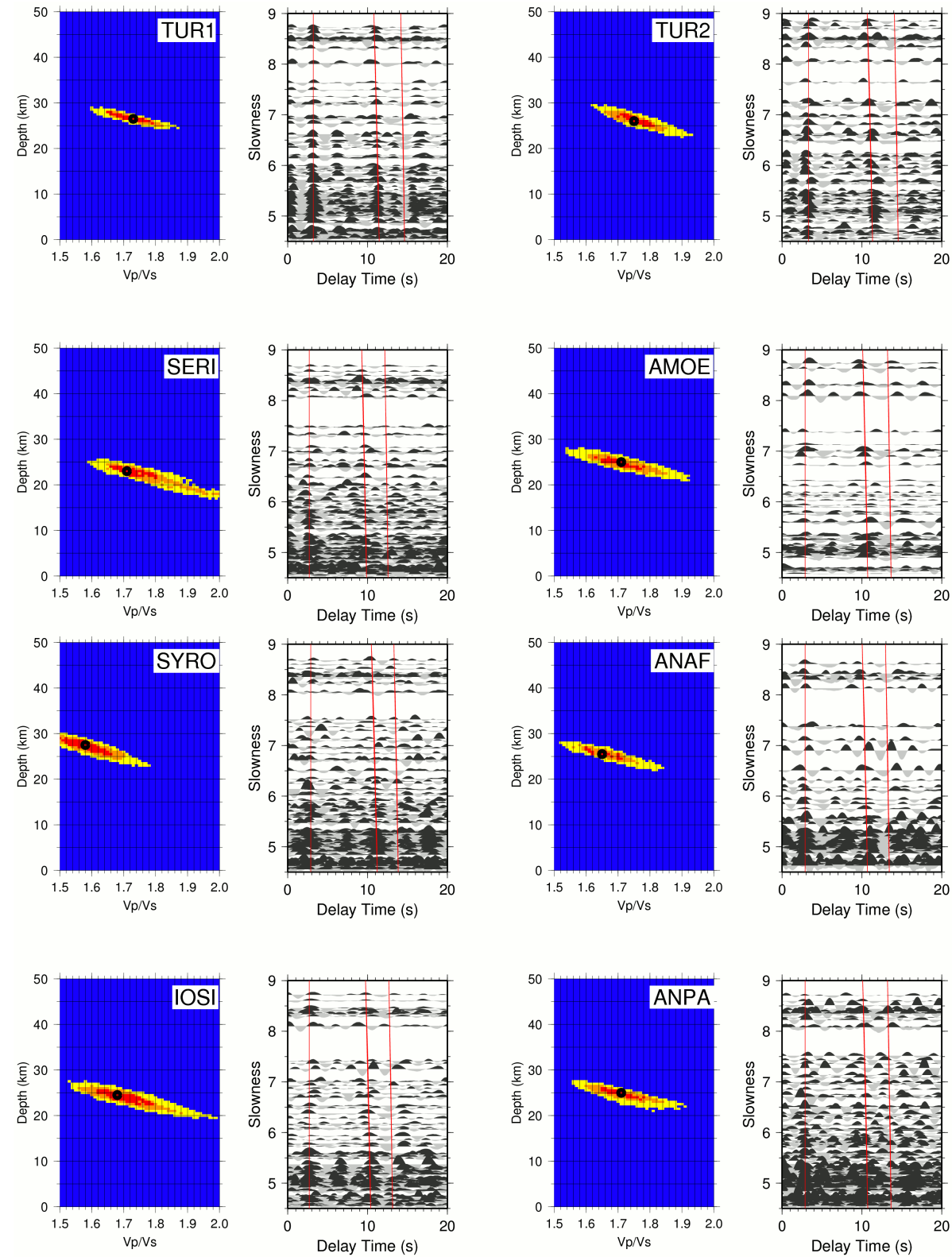

Figure 4. Examples of the Zhu and Kanamori (2000) method applied to PRFs. Black circle shows where the amplitudes of Ps, Ppps and Ppss + Psps phases are stacked most coherently and indicates the best Moho depth and Vp / Vs ratio beneath a station. Red thin lines on slowness sections (right) show theoretical arrival times for the direct Ps conversion and its first two multiples chosen for the best Moho depth and Vp / Vs ratio by the Zhu and Kanamori stacking technique.

Due to the unclear appearance of the Moho multiples at some stations, we also calculated the Moho depth regarding the arrival times of the Moho conversions. For this estimation, we used the modified IASP91 reference model (Kennett and Engdahl, 1991), in which the upper $180-200 \mathrm{~km}$ of the global IASP91 model was replaced by a regional minimum 1-D model obtained from the joint inversion of 1130 welllocated earthquakes of the EGELADOS catalogue (Brüstle et al, 2014). The calculated Moho depths are listed in Table 1 . These values seem mostly to be consistent with those obtained from the Zhu and Kanamori method. However, for stations showing high or low $\mathrm{Vp} / \mathrm{Vs}$ ratios the calculated crustal thickness may largely differ from that of the H-k stacking technique.

\subsubsection{Migration}

More detailed images can be provided by our migrated $\mathrm{P}$ receiver functions (Kind et al., 2002), in which the PRFs are back-projected along their ray paths and stacked within 
Table 1. Stations, their coordinates, observed arrival times of the converted Moho phase (Ps) and Moho multiple (Ppps) of the Aegean plate, corresponding Moho depths and Vp / Vs ratios obtained from the Zhu and Kanamori method, corresponding Moho depths obtained from the modified IASP91 reference model (using a reference distance of $67^{\circ}$ ).

\begin{tabular}{|c|c|c|c|c|c|c|c|}
\hline Station & Lat. & Long. & $\begin{array}{r}\text { Moho } \\
\text { time (s) }\end{array}$ & $\begin{array}{r}\text { Moho Multiple } \\
\text { time (s) }\end{array}$ & $\begin{array}{r}\text { Moho depth } \\
\text { Z\&K (km) }\end{array}$ & $\mathrm{Vp} / \mathrm{Vs}$ & $\begin{array}{l}\text { Moho depth modified } \\
\text { IASP91 }(\mathrm{km})\end{array}$ \\
\hline AMOE & 36.9150 & 25.9788 & 2.9 & 10.8 & 25 & 1.71 & 22 \\
\hline AMOS & 36.7956 & 25.7690 & 3.1 & 11 & 26.5 & 1.51 & 24 \\
\hline ANAF & 36.3581 & 25.7783 & 2.9 & 11.4 & 25.5 & 1.65 & 22 \\
\hline ANDR & 37.8361 & 24.9482 & 2.7 & 10.8 & 24.5 & 1.78 & 20 \\
\hline ANID & 36.6251 & 25.6847 & 2.4 & 9.5 & 22.5 & 1.67 & 18 \\
\hline ANPA & 37.0323 & 25.0763 & 2.9 & 10 & 25 & 1.71 & 22 \\
\hline APE & 37.0689 & 25.5306 & 3.4 & 10.9 & 24 & 1.83 & 27 \\
\hline ASTY & 36.5795 & 26.4114 & 3.4 & 10.5 & 23.5 & 1.83 & 27 \\
\hline AT01 & 38.06 & 24.3784 & 2.3 & 9 & 27.5 & 1.51 & 17 \\
\hline АT02 & 38.0473 & 23.8638 & 2.8 & 11 & 26 & 1.67 & 21 \\
\hline АT03 & 38.0268 & 23.4677 & 3.8 & 12 & 21 & 1.99 & 30.5 \\
\hline AT04 & 37.7252 & 24.0496 & 3.5 & 13 & 30.5 & 1.67 & 28 \\
\hline FOLE & 36.6216 & 24.9197 & 3 & 10 & 23 & 1.69 & 23 \\
\hline IDHR & 37.3908 & 23.2591 & 4.1 & 13.3 & 23.5 & 1.99 & 33.5 \\
\hline IKAR & 37.6435 & 26.3050 & 2.7 & 10 & 23 & 1.68 & 20 \\
\hline IOSI & 36.7347 & 25.3618 & 2.7 & 10.5 & 24.5 & 1.68 & 20 \\
\hline KEAI & 37.6232 & 24.3191 & 2.9 & 11.6 & 28 & 1.65 & 22 \\
\hline KIMO & 36.7949 & 24.5680 & 2.3 & 7.5 & 29.5 & 1.5 & 17 \\
\hline KOSI & 36.7449 & 26.9517 & 3 & 11.4 & 20 & 1.9 & 23 \\
\hline LERO & 37.1634 & 26.8353 & 3.1 & 11.5 & 26.5 & 1.7 & 24 \\
\hline MYKO & 37.4822 & 25.3844 & 2.8 & 11.2 & 27.5 & 1.57 & 21 \\
\hline NAXO & 36.9800 & 25.4400 & 2.5 & 9.2 & 26.5 & 1.63 & 19 \\
\hline NEAK & 36.4087 & 25.4014 & 2.85 & 11.4 & 28 & 1.61 & 21.5 \\
\hline PARO & 37.1150 & 25.1825 & 3.3 & 10.4 & 22.5 & 1.87 & 29 \\
\hline PARS & 37.0285 & 25.2253 & 2.9 & 10.6 & 25 & 1.68 & 22 \\
\hline PE01 & 38.0170 & 22.0283 & 4.3 & 13.5 & 31 & 1.86 & 35 \\
\hline PE02 & 37.8958 & 22.4907 & 6 & 21 & 45 & 1.72 & 51.5 \\
\hline PE03 & 37.3784 & 21.7722 & 4.5 & 15.5 & 40 & 1.83 & 37 \\
\hline PE04 & 37.6007 & 22.9593 & 4.8 & 16.2 & - & - & 39.5 \\
\hline PE05 & 37.5128 & 22.4553 & 5 & 18.2 & 43 & 1.83 & 41 \\
\hline PE07 & 37.1478 & 22.8195 & 3.5 & 12.1 & 27.5 & 1.8 & 28 \\
\hline PE08 & 36.8311 & 22.4420 & 4.3 & 14.8 & 33 & 1.81 & 35 \\
\hline SAMO & 37.7043 & 26.8377 & 3.4 & 12 & 26 & 1.79 & 27 \\
\hline SANT & 36.371 & 25.459 & 4 & 14.1 & 32 & 1.71 & 32.5 \\
\hline SCHI & 36.8744 & 25.5180 & 3 & 10.3 & 22.5 & 1.78 & 23 \\
\hline SERI & 37.1610 & 24.4853 & 2.7 & 10 & 23 & 1.71 & 20 \\
\hline SYRO & 37.4569 & 24.9266 & 2.9 & 10.5 & 27.5 & 1.58 & 22 \\
\hline TILO & 36.4485 & 27.3535 & 3.4 & 11 & 23 & 1.88 & 27 \\
\hline TUR1 & 38.0865 & 26.8676 & 3.2 & 11.4 & 26.5 & 1.73 & 25 \\
\hline TUR2 & 37.6420 & 27.2418 & 3.3 & 11.8 & 26 & 1.75 & 26 \\
\hline TUR3 & 37.4663 & 27.5380 & 3.5 & 11.1 & 28 & 1.78 & 28 \\
\hline TUR4 & 37.0800 & 27.8077 & 3.5 & 12 & 28 & 1.79 & 28 \\
\hline TUR5 & 37.0302 & 27.3167 & 3.3 & 11.7 & 27 & 1.75 & 26 \\
\hline TUR6 & 37.0159 & 28.4262 & 3.3 & 11.4 & 26.5 & 1.98 & 26 \\
\hline TUR7 & 36.7017 & 27.5697 & 3.8 & 13.5 & 28 & 1.81 & 30.5 \\
\hline TUR8 & 36.8273 & 28.9390 & 3.2 & 11.5 & 25 & 1.79 & 25 \\
\hline TUR9 & 36.7015 & 28.0887 & 3.5 & 12 & 30.5 & 1.68 & 28 \\
\hline
\end{tabular}


small bins $(2 \mathrm{~km} \times 2 \mathrm{~km})$. The conversion points are calculated by ray tracing using the modified IASP91 reference model. Figure 5 shows depth migrations of PRFs down to $80 \mathrm{~km}$ depth along the eight S-N profiles shown in Fig. 1. Accurate hypocentre locations of temporary network catalogues are also shown in Fig. 5b (profiles 5-8). High-frequency $P$ receiver functions reliably indicate the presence of the Aegean and African plates. The continental Aegean Moho can be well seen beneath the northern part of all profiles up to the forearc area (labelled Moho, see Fig. 5). The thickest crust of about $48-50 \mathrm{~km}$ is observed beneath the Peloponnese Peninsula, where the Hellenides mountains are located (see profile 1, Fig. 5a). We found relatively thinner crust of approximately $27-30 \mathrm{~km}$ beneath the stations located in western Turkey (see profile 8, Fig. 5b). The Aegean crust becomes thinner and is approximately $23-28 \mathrm{~km}$ thick beneath the central Aegean Sea. These results are in good agreement with those obtained from the previous PRF studies in western Anatolia, Peloponnese and in central Aegean (e.g. Sodoudi et al., 2006; Zhu et al., 2006; Karabulut et al., 2013; Vanacore et al., 2013). Relatively thin crust beneath the Aegean and adjacent areas likely shows the extensional tectonics that affected the whole Aegean since the Oligocene time $(\sim 30 \mathrm{Ma})$ (e.g. Mascle and Martin, 1990).

Further south, beneath the forearc area, the Moho phase is no longer visible and is continued by negative converted phases. This is a common feature, which can be reliably observed beneath the forearc on all profiles. However, we could not clearly image the transition from Moho to the negative signal (except beneath profile 8 in western Turkey) due to the gap of stations in the Cretan Sea. The negative phase indicates a low-velocity zone (LVZ), which was previously reported and interpreted as serpentinized mantle wedge above the subducting plate (e.g. Endrun et al., 2004; Sodoudi et al., 2006). Very low shear velocities in the forearc mantle were first observed and interpreted by Bostock et al. (2002) in Cascadia. They called their observation "inverted Moho" since the sign of the converted signal has the opposite polarity of the usual Moho conversion. Interestingly, this low-velocity zone shows also low seismicity (see Fig. 5b), whereas the high seismicity occurs just above or below it. From profile 5where accurate locations of seismic events at the seismogenic interface are available (Becker et al., 2009) - it becomes evident that the plate contact between the serpentinized mantle and the subducting plate is mainly aseismic. Thus, the serpentinized mantle wedge is deforming mainly aseismically. On the other hand the seismogenic zone seems to terminate where the serpentinized mantle wedge comes in contact with the plate interface (see Fig. 5b). Meier et al. (2007) noted that the seismogenic zone terminates at the southern coastline of Crete and postulate that the recent uplift of Crete is related to the return flow above the seismically decoupled plate interface. Here we show that the serpentinized mantle wedge is present along the entire forearc of the Hellenic subduction zone and its location coincides with the location of the
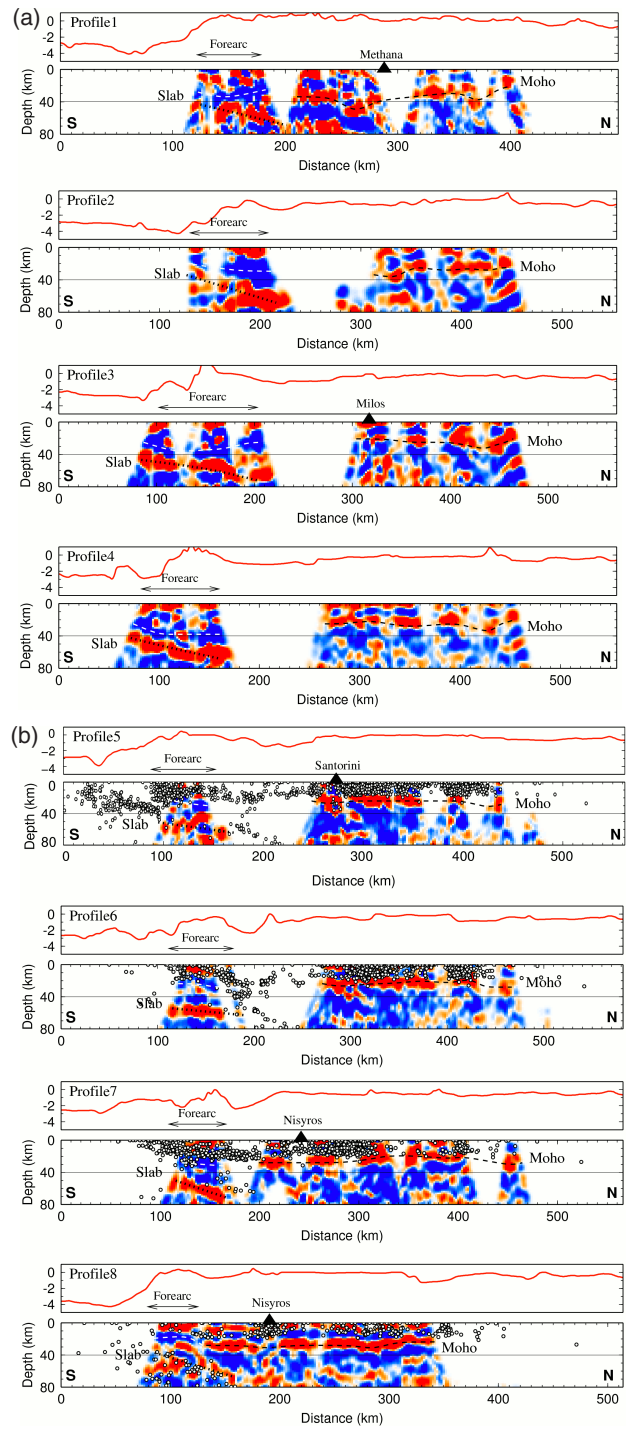

Figure 5. Migrated PRFs along $\mathrm{S}-\mathrm{N}$ trending profiles shown in Fig. 1. Topography is shown at the top. Positive (negative) phases are shown in red (blue). Positions of the volcanoes are shown with black triangles. (a) For the western profiles (1-4): the Moho of the continental Aegean plate (black dashed lines, labelled Moho) is well observed beneath the profiles up to the forearc region. This phase is not visible beneath the forearc area and seems to be continued as negatively converted phases (white dashed lines). The subducted African Moho (black dotted lines, labelled Slab) is well observed beneath the forearc area at depths ranging from 40 to $80 \mathrm{~km}$. Note that the thickest crust of about $48-50 \mathrm{~km}$ is seen beneath the Peloponnese (profile 1). (b) As (a) for the eastern profiles (5-8). The black circles show the seismicity of the temporary network catalogues (Becker et al., 2009; Brüstle et al., 2014). Note that the most seismicity occurs above or below the serpentinized mantle wedge (negative phases in blue) beneath the forearc area. Note that the slab is also observed in the distance range between 100 and $170 \mathrm{~km}$ where no seismicity is observed (on profiles 5-7). 
forearc high (see upper panels in Fig. 5 for topography). Furthermore, the slab is clearly imaged beneath the forearc area throughout the whole region at depths ranging from 40 to $80 \mathrm{~km}$ (Fig. 5). As Fig. 5b shows, the seismicity (for profiles 5-8) is also consistent with the $\mathrm{P}$ receiver function results. Both the $\mathrm{P}$ receiver functions and the hypocentre locations constrain the geometry of the slab.

\subsection{Subducted African slab}

\subsubsection{Hypocentre locations}

The geometry of the Wadati-Benioff zone (WBZ) is shown by three cross-sections along profiles 5-7 in Fig. 6 (see also Fig. 1). Profile 5 shows the WBZ of the central Hellenic Subduction Zone from the forearc high in eastern Crete to the Hellenic volcanic arc near the Santorini volcano (station SANT). Hypocentre locations are projected onto the profile with a maximum distance of $30 \mathrm{~km}$ to each side. Further to the north ( $\sim 100 \mathrm{~km}$ distance), a nearly aseismic zone of about $50 \mathrm{~km}$ width is identified beneath eastern Crete. A nearly continuous WBZ from $50 \mathrm{~km}$ depth down to $190 \mathrm{~km}$ (beneath the volcanic arc) is delineated by hypocentre locations. The WBZ dips with an angle of about $26^{\circ}$ down to $100 \mathrm{~km}$ to the north. Further to the north the dip angle increases up to $45^{\circ}$. Profile 6 shows the seismicity along the slab from the region between Crete and Karpathos (station KAPA) in the forearc high to the region between the two volcanic centres with a total profile width of $40 \mathrm{~km}$. The geometry of the WBZ is in good agreement with that along profile 5. However, a cluster with an offset of about $40 \mathrm{~km}$ is identified beneath the WBZ. Further to the east along profile 7 , a cluster of high seismic activity is observed beneath the volcano region. The seismicity of the cluster corresponds to the position of the eastern WBZ along profile 6 with the same orientation and dip angle $\left(\sim 35^{\circ}\right)$ to NNW. The lack of seismicity beneath eastern Crete and further to the east, which is observed on profiles 5-7 (distance 100-150 km) coincides with the negative Moho velocity contrast observed by PRFs and points to a serpentinized mantle wedge (see Fig. 5).

\subsubsection{P receiver functions}

To follow the continuation of the slab at larger depths, we firstly calculated P-to-S conversion points at $200 \mathrm{~km}$ depth using the modified IASP91 reference model. This depth was chosen based on the previous $\mathrm{S}$ receiver function study, which exhibited the continuation of the slab down to 180$200 \mathrm{~km}$ beneath the central Aegean (Sodoudi et al., 2006). For each profile, we considered the PRFs, whose piercing points are located within the data band of $60 \mathrm{~km}$ from each side of the profile. Then we stacked them in bins of $4 \mathrm{~km}$ and sorted them according to their distance from the starting point of the profile (see Fig. 1). Figure 7 indicates the binned PRFs along the eight profiles shown in Fig. 1. Be-

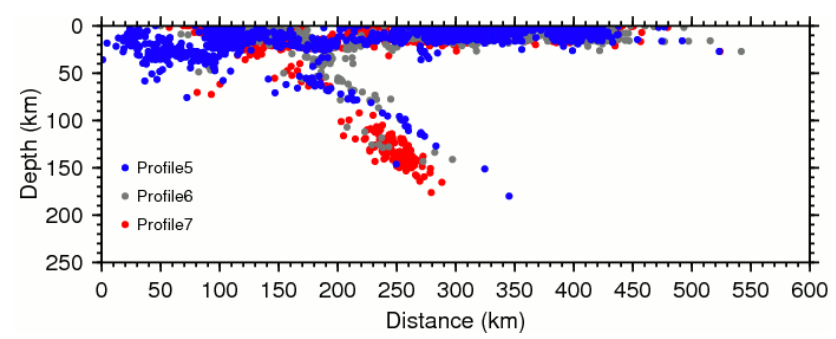

Figure 6. Hypocentre locations along the WBZ. Additionally to the hypocentre locations of the CYYNET and EGELADOS networks, hypocentre locations of the temporary LIBNET (Becker et al., 2009) are also projected. Hypocentre locations along profiles 57 are plotted in different colours. A cluster with an offset of about $40 \mathrm{~km}$ is identified beneath the WBZ along profile 6 . The position, orientation and dip angle of this cluster corresponds with those of a cluster of high seismic activity along profile 7 . The lack of seismicity at distances between 100 and $150 \mathrm{~km}$ coincides with the negative Moho velocity contrast observed by PRFs (see Fig. 5).

sides the Moho conversions (black boxes) with different polarities changing from negative in the forearc to positive in the back arc and the Moho multiples (white dashed lines), there are also significant conversions from the subducting African Moho (black dashed lines). It is important to note that Fig. 7 is more appropriate for deeper phases such as converted phases from the slab. Distribution of P-to-S conversions at $200 \mathrm{~km}$ cannot provide accurate images of the Moho variations (for more accurate Moho estimations see Fig. 5).

For each profile, local seismicity (Engdahl et al., 1998; Becker et al., 2009; Brüstle et al., 2014) is overlaid on the PRF data. The WBZ of the subducting African plate can continuously be traced down to about $100 \mathrm{~km}$ in the western and to about $180 \mathrm{~km}$ in the eastern subduction zone, and its dip direction changes from $\mathrm{E}$ in the western to $\mathrm{N}$ in the central to NW in the eastern part with an increasing dip angle from $\mathrm{W}$ $\left(\sim 25^{\circ}\right)$ to $\mathrm{E}\left(\sim 35^{\circ}\right)$ (Brüstle et al., 2014). Clusters of high microseismicity have been observed beneath the volcanic arc (see profile 7, Fig. 7). Generally, there is a good correlation between the geometry of the slab shown by seismicity and that obtained from the PRFs. Both of them can satisfactorily resolve the shallower part of the slab down to at least $90 \mathrm{~km}$ depth $(\sim 10 \mathrm{~s})$.

Our results together with seismicity enabled us to image the slab more accurately, especially for the eastern Hellenic subduction zone, where the resolution of the seismicity of the temporary network catalogues (profiles 5-8) is better than $20 \mathrm{~km}$ with an average location uncertainty of less than $10 \mathrm{~km}$ as estimated by the location routine NonLinLoc (Becker et al., 2009; Brüstle et al., 2014). Regarding the dominant wave periods of the $\mathrm{P}$ wave (approximately $2 \mathrm{~s}$ ), a maximum depth resolution of about $2 \mathrm{~km}$ can be theoretically estimated for Pto-S conversions at discontinuities. Considering some more errors obtained from the velocity model (Brüstle et al., 2014) as well as those from lateral heterogeneities and noise, we 

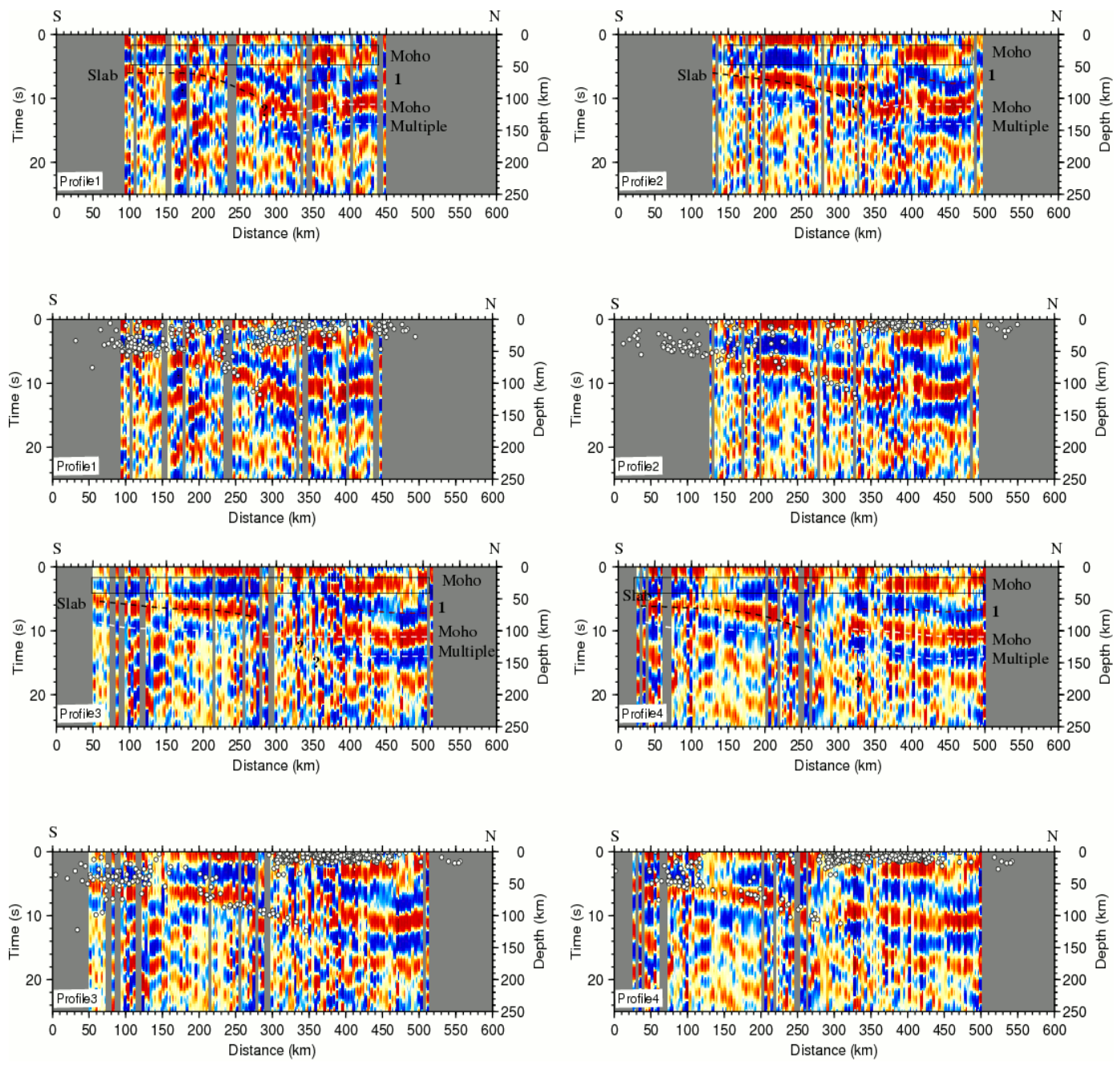

Figure 7. Sections obtained from the binned PRF data in $4 \mathrm{~km}$ bins (upper panels) along profiles shown in Fig. 1. Seismicity is also overlaid on the PRF sections (lower panels, small white circles). Positive (negative) conversions are shown in red (blue). The data are filtered with a band-pass filter of 4-30 s. A black box represents the rough location of the Moho boundary, which shows a significant polarity change from the forearc (negative) to the back arc (positive). White dashed lines indicate the Moho multiples, whose polarities are also related to those of the Moho conversions. The shallow part of the downgoing African slab (black dashed lines) is well imaged by PRFs and correlates with the seismicity. Question marks show the same arrival time of the first Moho multiple (shown in red) and the slab phase or weak indications of the continuation of the slab. Note that the strong negative conversion at 4-7 s (dark red dashed lines, marked as 1 in all profiles) may show a LVZ just below the Aegean Moho phase (see also Fig. 8).

expect to have an uncertainty of less than $5 \mathrm{~km}$ in depth estimation for the Moho and less than $10 \mathrm{~km}$ for the slab. In contrast, resolution of tomographic surface wave and body wave studies is in general lower. Furthermore, previous $\mathrm{P}$ receiver function studies could not image the Hellenic slab deeper than $120 \mathrm{~km}$ depth (Knapmeyer and Harjes, 2000; Li et al., 2003; Endrun et al., 2004; Sodoudi et al., 2006). In this work, in particular the comparison of $\mathrm{P}$ receiver functions with hypocentres of the WBZ allows us to distinguish between primary conversions from the slab and multiples of the Moho. Multiples could otherwise be misinterpreted as flat slabs.
Our results mainly show a relatively shallow dipping slab segment $\left(\sim 25^{\circ}\right)$ beneath the western part of the Aegean (profiles 1-4, Fig. 7). Along profile1 located in the westernmost part of the Aegean, the slab is consistently imaged at times ranging from $5 \mathrm{~s}$ to about $11 \mathrm{~s}$ (black dashed line). Further north, the continuation of the slab is not clear. The arrivals of the Moho multiples (white dashed line) with positive amplitudes make the identification of the converted slab phase difficult (black question mark). Beneath profile 2, the converted slab phase is visible until 10-12 s, where the seismicity stops. The slab phase in profile 3 is resolved at depths up to $80 \mathrm{~km}$ (or $\sim 8 \mathrm{~s}$ ). 

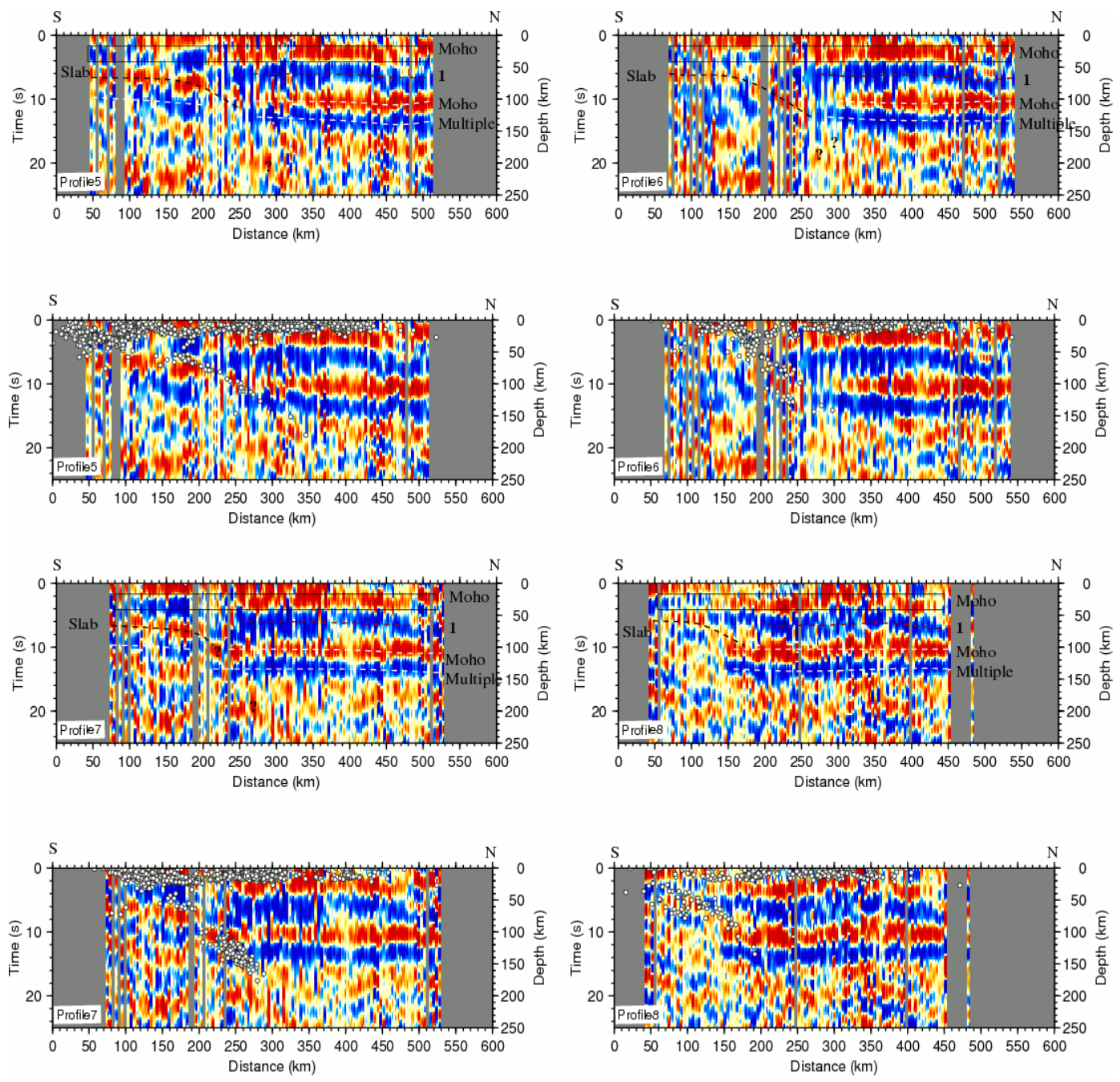

Figure 7. Continued.

The PRFs along profile 4 are similar to those observed along profiles $1-3$. The slab down to $\sim 10 \mathrm{~s}$ is well resolved by PRFs along profile 4 . Strong appearance of the Moho multiples with negative amplitudes at the arrival time of the slab phase at about $10 \mathrm{~s}$ do not permit clear signals in larger depths.

Along profile 7, the converted slab phases are visible down to $10 \mathrm{~s}$ in contrast to seismicity, which shows a cluster down to $180 \mathrm{~km}$ depths beneath profile 7 . PRFs along profile 8 cannot confirm the presence of the slab at depths larger than $70 \mathrm{~km}$. At depths larger than $80-100 \mathrm{~km}$ the slab may be formed by continental rather than oceanic lithosphere because according to tectonic reconstructions not more than about 500 to $700 \mathrm{~km}$ of oceanic lithosphere has been subducted at the recent Hellenic arc (Meier et al., 2004; van Hinsbergen, 2005; Brun and Sokoudis, 2010). However, the available data do not permit a clear result.

\section{Discussion}

Based on hypocentre locations shown in Fig. 6, the eastern Hellenic subduction zone is divided into two portions by the intense seismic deformation of the Aegean plate in the region between eastern Crete and Karpathos (station KAPA, see Fig. 1). On the subducting slab this zone of high deformation is characterized by a vertical offset of about $40 \mathrm{~km}$ of the WBZ beneath the eastern Cretan Sea (Fig. 6). This deformation zone separates a shallower $\mathrm{N}$-ward dipping slab in the west from a steeper NW-ward dipping slab in the east (Brüstle, 2012). The change of the dipping is also expressed by the observed seismicity of the overriding Aegean plate. The seismogenic zone between about 20 and $40 \mathrm{~km}$ depth of the plate interface is currently seismically active in the southwestern Aegean. This is in contrast to the seismogenic zone in the southeastern Aegean in the region of Rhodes. These differences support a segmentation of the Hellenic subduction zone in the western and eastern part. The low seismicity in 
the seismogenic zone in the southeastern Aegean may indicate either a low seismic coupling or a locked interface. The different influence of the slab kinematics onto the Aegean plate can also be associated with local variations of GPS velocities and their orientation relative to the central Aegean plate. Velocity vectors of the western region of the eastern Hellenic Subduction Zone are relatively small and preferably S- or SSE-oriented. Relative GPS velocity vectors of the eastern part of the eastern Hellenic Subduction Zone are larger and clearly SE-oriented (McClusky et al., 2000; Reilinger et al., 2010), which may indicate low seismic coupling and a more aseismic deformation along the plate interface in the seismogenic zone in the southeastern Aegean.

The lower dip angle of the western $\mathrm{WBZ}\left(\sim 25^{\circ}\right)$ and low GPS velocities may point to reduced rollback rates of the African plate. In contrast, in the Rhodes region of the eastern Hellenic subduction zone, where the slab is dipping to NW under larger dip angle $\left(\sim 35^{\circ}\right)$, the WBZ is observed to greater depths $(\sim 180 \mathrm{~km})$ and high GPS velocities may reveal a still active rollback of the African lithosphere to the SE.

These findings (Brüstle, 2012) provided excellent constraints on the geometry of the WBZ, where the resolution of the slab geometry by other studies (e.g. seismicity and tomographic studies) was limited (e.g. Spakman et al., 1993; Knapmeyer, 1999; Papazachos et al., 2000; Meier et al., 2007).

We found evidence for a shallow dipping segment $\left(\sim 25^{\circ}\right)$ down to $\sim 100 \mathrm{~km}$ depth beneath the convergent western part (profile 1-4), whereas the presence of the steeper slab beneath the eastern part is not resolved in our PRFs (profiles 6 and 7, Fig. 7). Very weak conversions observed at larger depths may be related to reduced velocity contrasts implying eclogitization of crustal materials.

Evidence for west-east segmentation of the Hellenic slab was previously suggested by analysing hypocentres of the relocated EHB-ISC catalogue (Engdahl et al., 1998). Meier et al. (2007) identified two slab segments and proposed that they are associated with laterally varying properties of the African slab. Furthermore, in the Mediterranean southeast of Crete, Rhodes and south of western Anatolia, high velocities in the mantle lithosphere - typical for cold oceanic lithosphere - are found by tomographic studies (Bijward et al., 1998; Marone et al., 2004; Endrun et al., 2008; Legendre et al., 2012), whereas south of Peloponnese and western Crete velocities in the mantle lithosphere are lower (Meier et al., 2004; Legendre et al., 2012).

Regional body-wave tomographic study (Papazachos and Nolet, 1997) clearly showed a strong NW-SE delineation of the shallow dipping $\left(\sim 25^{\circ}\right)$ and larger western part of the slab. However, the geometry of the smaller eastern part was not resolved probably due to the poor ray geometry. Based on these results, a steeper non-continuous highvelocity anomaly (dip of $\sim 35^{\circ}$ ) was seen beneath the eastern part of the subduction forming a more or less right angle at about $200 \mathrm{~km}$ depth with the shallower and larger western part of the slab.

The dip of the western segment $\left(\sim 25^{\circ}\right)$ obtained from our data is in good agreement with that $\left(\sim 21^{\circ}\right)$ shown along the western Hellenic subduction zone using a recently developed imaging technique (2-D GRT), which inverts the teleseismic scattered P-wave coda for discontinuities in elastic properties (e.g. Suckale et al., 2009; Pearce et al., 2012). Our results are also consistent with those derived from regional body-wave travel-time tomography for the western Hellenic subduction zone (e.g. Papazachos and Nolet, 1997), which found evidence for a western (dip of $25^{\circ}$ ) and eastern (dip of $35^{\circ}$ ) slab segment. We do not find evidence for a horizontally propagating tear beneath Peloponnese in the region of the western segment of the Hellenic subduction zone as reported by Wortel and Spakman (2000). If present, the horizontal tear is confined to the northern Hellenides beneath mainland Greece north of the Peloponnese and the Gulf of Corinth.

Regarding our PRF images, we cannot confirm the presence of two different segments of the African slab. This is in contrast to hypocentre locations, which infer that the transition between the western and eastern segments may occur beneath profiles 5 and 6 crossing the eastern Cretan Sea (see Fig. 6). In general, seismicity and receiver functions are compatible at shallower depths $(\sim 100 \mathrm{~km}$ depth $)$ as the location uncertainty of microseismicity by temporary networks and the spatial resolution of receiver function imaging are comparable. However, strong multiple arrivals as well as complete phase transitions into denser phases, which results in very weak conversions, may be considered as responsible reasons for the non-coincidence of the seismicity data with PRFs at larger depths.

Furthermore, PRF data may resolve another dominant negative phase at 4-7 s (Fig. 7, dark red dashed lines, marked as 1). This phase is clearly seen beneath the northern part of all profiles just below the Aegean Moho phase. To evaluate the coherency of this phase, we stacked around 785 PRFs beneath the northern part of profile 5 (distance of 360$520 \mathrm{~km}$ on the profile line), where this phase is best imaged. The stacked PRF includes PRFs with different epicentral distances ranging between $30^{\circ}$ and $95^{\circ}$. We filtered the stacked PRF with different low-pass filters and show them in Fig. 8. Presence of two negative phases in the first $8 \mathrm{~s}$ of the stacked PRF can be clearly observed using different filters. The large positive and negative signals between 10 and $20 \mathrm{~s}$ are crustal multiples.

Low velocities below $60 \mathrm{~km}$ depth beneath the southern Aegean and the volcanic arc have been earlier observed by P-wave tomography (Drakatos et al., 1997; Papazachos and Nolet, 1997). In addition, surface wave dispersion analysis revealed a low-velocity layer with minimum velocities of $4.15 \mathrm{~km} \mathrm{~s}^{-1}$ at depths of $50-70 \mathrm{~km}$ between the Aegean Moho and the slab in the Cretan Sea and beneath the central Aegean (Karagianni et al., 2002; Endrun et al., 2008). An even more pronounced low-velocity layer was found by 


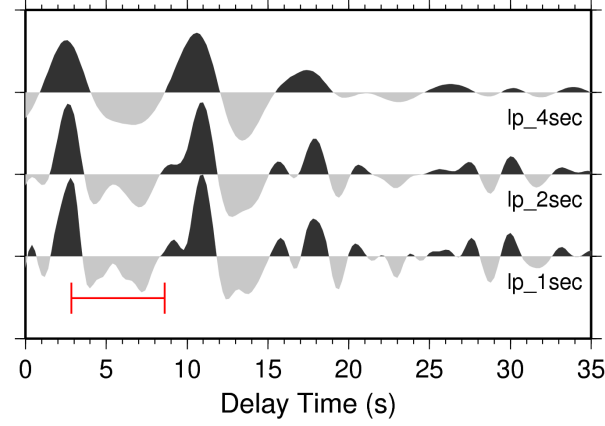

Figure 8. Stacked PRF obtained from the northern part of profile 5 (distance of $360-520 \mathrm{~km}$ on the profile line, see Fig. 7). Different low-pass filters were applied to the stacked trace. Independently of the corner frequency of the filter, significant negative signals are visible in the first $8 \mathrm{~s}$ of the seismogram (shown with thin red line). The signals between 10 and $20 \mathrm{~s}$ are crustal multiples.

Bourova et al. (2005). They observed a large low-velocity anomaly at a depth of $50-100 \mathrm{~km}$ beneath the prolongation of the North Anatolian Trough in the northern Aegean, where strong deformation is currently observed at the surface. However, evidence for a LVZ beneath the Aegean plate has not been reported by previous PRF studies.

We have observed the most pronounced and sharp lowvelocity zone (6\% velocity reduction) at about $60 \mathrm{~km}$ beneath the back arc area (after volcanic arc, see Fig. 1), where no estimation of the lithospheric thickness was made before. The observed LVZ has been constrained consistently between the Moho of the Aegean plate and the slab (see Fig. 7) along all profiles (dark red dashed lines). The depth of our LVZ is consistent with that derived from P-wave tomography and surface wave analysis in the northern and central Aegean (Drakatos et al., 1997; Papazachos and Nolet, 1997; Karagianni et al., 2002; Endrun et al., 2008; Bourova et al., 2005).

Previous S receiver function analysis (Sodoudi et al., 2006) provided earlier constraints on the LAB depth in the Aegean. The $\mathrm{S}$ receiver function data resolved LAB signals at about $170 \mathrm{~km}$ beneath mainland Greece and at $130 \mathrm{~km}$ beneath western Turkey (Fig. 9). Due to the locations of the EGELADOS stations we could not provide any estimation of the Aegean LAB beneath mainland Greece in this work. Furthermore, for the central Aegean, no $S$ receiver function data are available yet. We show in Fig. 9b stacked PRFs obtained from the boxes located beneath the northern parts of the study area, where the negative phase at 4-7 s was significantly observed in our PRFs (see Fig. 7). We combined our results with those previously shown by Sodoudi et al. (2006) using S receiver functions. Stacked PRFs computed for each box (see Fig. 9a) are illustrated along a W-E trending profile covering the central Aegean. We also included the stacked SRFs obtained from five boxes mostly located beneath the mainland Greece and western Turkey from Sodoudi et al. (2006). As
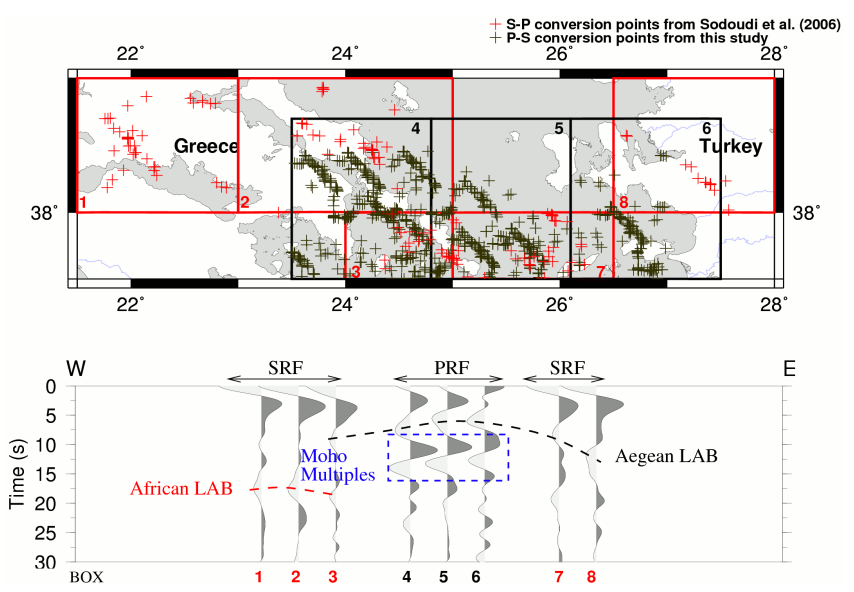

Figure 9. Aegean LAB as seen by PRFs from this study compared with the results obtained from SRFs by Sodoudi et al. (2006). (a) Location of P-to-S (black crosses) and S-to-P (red crosses) piercing points. Red boxes (black boxes) show where the SRFs (PRFs) are stacked. (b) Summation traces of $\mathrm{P}$ and $\mathrm{S}$ receiver functions obtained from the boxes shown in (a). The Aegean LAB may lie at about 6-8s beneath the central Aegean (boxes 4-6) with a significant deepening to about $10 \mathrm{~s}$ towards Turkey (box 7). The African LAB as presented by Sodoudi et al. (2006) is shown with red dashed line beneath mainland Greece and western Aegean (boxes 1-3). Blue dotted rectangle shows the arrival time window of the Moho multiples.

Fig. 9b shows, the $\mathrm{P}$ and $\mathrm{S}$ receiver functions yield consistent results for the LAB signal if multiples in the $\mathrm{P}$ receiver functions are carefully identified (compare box 3 with box 4 and box 6 with box 7). Beneath mainland Greece the LAB is found at about $17 \mathrm{~s}(\sim 170 \mathrm{~km})$. This can be seen in boxes 13 . This signal indicates very likely the bottom of the subducting lithosphere in the region of boxes 1 and 2 . The negative signal resolved at 6-8 $\mathrm{s}$ beneath the central Aegean (boxes 4-6) is very clear in our PRFs and may represent the Aegean LAB. Furthermore, the signal at about $10 \mathrm{~s}(\sim 100 \mathrm{~km})$ in boxes 7 and 8 showing the Aegean LAB in western Anatolia would imply a thickening of the Aegean lithosphere towards Anatolia.

If the negative discontinuity at about $60 \mathrm{~km}$ depth represents the lithosphere-asthenosphere boundary (LAB) of the continental Aegean plate (in good agreement with Endrun et al., 2008), this will be a remarkable result as it indicates a very thin mantle lithosphere in the central and northern Aegean. Taking the error bounds of $\mathrm{P}$ receiver functions $( \pm 5 \mathrm{~km})$ into account, we found a relatively thicker lithosphere in the central Aegean $(60 \mathrm{~km})$ rather than that seen by surface waves analysis beneath the southern Aegean between forearc and volcanic arc (40-50 km) (Endrun et al., 2008). Given a crustal thickness of about $23-27 \mathrm{~km}$ in the central Aegean, the mantle lithosphere appears to be about $30-40 \mathrm{~km}$ thick. Although there is evidence for lithospheric stretching during the extensional processes governing the more recent 
(last $30 \mathrm{Ma}$ ) evolution of the Aegean, the interpretation of a thinned mantle lithosphere would imply a greater thickness of the mantle lithosphere before $30 \mathrm{Ma}$. Based on tectonic reconstructions (Dercourt et al., 1986; Gealey, 1988; Stampfli and Borel, 2004), the continuous slab (down to a depth of approximately $1200 \mathrm{~km}$ ) imaged by seismic tomography would be composed of different sections of oceanic and continental mantle lithosphere (Meier et al., 2004; van Hinsbergen et al., 2005), corresponding to the oceanic basins and continental terranes. Delamination of the continental crust of the terranes from the underlying continental mantle lithosphere has been proposed in order to explain the rather continuous slab (Meier et al., 2004), nappe stacking and metamorphism in the Aegean (van Hinsbergen et al., 2005, Jolivet and Brun, 2010) based on the geological record of Crete (e.g. Thomson et al., 1998) and has been suggested as the reason for the missing deep seismicity in the Hellenic subduction zone (Meier et al., 2004).

Similarly, delamination of the Anatolian mantle lithosphere has been proposed by Keskin (2003). The removal of the mantle lithosphere of accreted continental terranes would mean that despite the lithospheric extension the mantle lithosphere has gained again a thickness of about $30-40 \mathrm{~km}$ in the central Aegean since its removal about 35 to $15 \mathrm{Ma}$ ago. Processes involved in the evolution of a younger mantle lithosphere may be cooling of the asthenospheric mantle, magmatic underplating, dehydration of serpentinized mantle, or chemical differentiation of crustal material (Artemieva and Meissner, 2012).

\section{Conclusions}

We analysed more than 1.5 years of teleseismic data recorded by 65 temporary and permanent stations of EGELADOS network. By combining $\mathrm{P}$ receiver function observations and new accurate locations of seismic events, we obtained a detailed image of the subducting African plate beneath the continental Aegean plate in the southern and central Aegean. Observation of the negative Moho velocity contrast of the Aegean plate along the entire forearc clearly showed the serpertinized mantle wedge over the subducted African plate. Furthermore, the plate contact between the serpentinized mantle and the subducting plate seems mainly to be aseismic. We also constrained accurate crustal thicknesses and $\mathrm{Vp} / \mathrm{Vs}$ ratios for the continental Aegean plate, since it could be sampled at the spacing of the EGELADOS stations. Low $\mathrm{Vp} / \mathrm{Vs}$ ratios were observed beneath the central Aegean, which most likely reveal felsic crustal composition of the continental Aegean plate. Moreover, we identified the thickest crust of about $48-50 \mathrm{~km}$ beneath the Peloponnese Peninsula, whereas a relatively thinner crust of about $27-30 \mathrm{~km}$ was observed beneath the western Turkey. The crust of the Aegean plate was estimated to be $23-27 \mathrm{~km}$ thick beneath the southern and central Aegean. PRFs significantly imaged the Moho of the subducting African plate as a strong converted phase at shallower depths (down to $100 \mathrm{~km}$ ) in excellent agreement with the spatial distribution of the earthquake hypocentres. We compared PRFs to hypocentres of the relocated EHB-ISC catalogue (Engdahl et al., 1998) beneath the western Aegean. In the southeastern Aegean, PRFs were compared with microseismicity obtained from the accurately located EGELADOS and relocated CYCNET catalogues (Brüstle et al., 2014) as well as accurate locations from the LIBNET network (Becker et al., 2009). The geometry of the subducted African Moho was obtained along eight different profiles covering the southern and central Aegean. Our results mainly resolved a low dip angle slab segment $\left(\sim 25^{\circ}\right)$ down to $100 \mathrm{~km}$ depth beneath the western Aegean. In contrast to the accurate hypocentre locations, which show a deformation zone separating a shallower $\mathrm{N}$-ward dipping slab in the west from a steeper $\left(\sim 35^{\circ}\right) \mathrm{NW}$-ward dipping slab in the east, we could not find any evidence for the presence of a steeper and deeper slab segment beneath the southeastern Aegean in PRF data. The absence of the converted slab phase at larger depths may support phase transitions and eclogitization of the oceanic crust towards larger depths. Based on our PRFs, a LVL at about $60 \mathrm{~km}$ depth may represent the LAB of the Aegean plate beneath the central Aegean. If only crustal material has been accreted to Eurasia due to the collision of Gondwana derived terranes, this would imply a growth of the Aegean mantle lithosphere of about 30$40 \mathrm{~km}$ in the last about 15 to $35 \mathrm{Ma}$.

Acknowledgements. Mobile seismic stations for the temporary networks were provided by the DEPAS and GIPP pools (GFZ Potsdam, AWI Bremerhaven). Furthermore, we thank NOA, Greece, GFZ Potsdam, and INGV, Rome, for data of permanent seismic networks. We also thank Hans Thybo, Wolfram Geissler, Xiaohui Yuan and three anonymous reviewers for their constructive comments. Funding was provided by the German Research Foundation in the framework of the Collaborative Research Centre 526 "Rheology of the Earth" and by GFZ Potsdam.

The service charges for this open access publication have been covered by a Research Centre of the Helmholtz Association.

Edited by: H. Thybo

\section{References}

Armijo, R., Meyer, B., King, G., Rigo, A., and Papanastassiou, D.: Quaternary evolution of the Corinth Rift and its applications for the late Cenozoic evolution of the Aegean, Geophys. J. Int., 126, 11-53, 1996.

Artemieva, I. M. and Meissner, R.: Crustal thickness controlled by plate tectonics: a review of crust-mantle interaction processes illustrated by European examples, Tectonophysics, 530-531, 1849, doi:10.1016/j.tecto.2011.12.037, 2012. 
Becker, D., Meier, T., Bohnhoff, M., and Harjes, H.-P.: Seismicity at the convergent plate boundary offshore Crete, Greece, observed by an amphibian network, J. Seismol., 14, 369-392, doi:10.1007/s10950-009-9170-2, 2009.

Bijwaard, H., Spakman, W., and Engdahl, E.R.: Closing the gap between regional and global travel time tomography, J. Geophys. Res., 103, 30055-30078, 1998.

Biryol, C. B., Beck, S. L., Zandt, G., and Özacar, A. A.: Segmented African lithosphere beneath the Anatolian region inferred from teleseismic P-wave tomography, Geophys. J. Int., 184, 10371057, 2011.

Bohnhoff, M., Makris, J., Papanikolaou, D., and Stavrakakis, G.: Crustal investigation of the Hellenic subduction zone using wide aperture seismic data, Tectonophysics, 343, 239-262, 2001.

Bohnhoff, M., Rische, M., Meier, T., Endrun, B., Harjes, H. P., and Stavrakakis, G.: CYC-NET: A temporary seismic network on the Cyclades (Aegean Sea, Greece), Seismol. Res. Lett., 75, 352357, 2004

Bohnhoff, M., Rische, M., Meier, T., Becker, D., Stavrakakis, G., and Harjes, H. P.: Microseismic activity in the Hellenic Volcanic Arc, Greece, with emphasis on the seismotectonic setting of the Santorini-Amorgos zone, Tectonophysics, 423, 17-33, 2006.

Bostock, M. G., Hyndman, D., Rondenay, S., and Peacock, S. M.: An inverted continental Moho and serpentinization of the forearc mantle, Nature, 417, 536-538, 2002.

Bourova, E., Kassara, I., Pedersen, H. A., Yanovskaya, T., Hatzfeld, D., and Kirtazi, A.: Constraints on absolute S-wave velocities beneath the Aegean Sea from surface wave analysis, Geophys. J. Int., 160, 1006-1019, 2005.

Brun, J.-P. and Sokoutis, D.: 45 m.y. of Aegean crust and mantle flow driven by trench retreat, Geology, 38, 815-818, doi:10.1130/G30950.1, 2010.

Brüstle, A. : Seismicity of the eastern Hellenic Subduction Zone, PhD Thesis, Ruhr University Bochum, 2012, available at: http://www-brs.ub.ruhr-uni-bochum.de/netahtml/HSS/ Diss/BruestleAndrea/diss.pdf (last access: 02 November 2012), 2012.

Brüstle, A., Meier, T., Rische, M., Küperkoch, L., Friederich, W., and the EGELADOS working group: Seismicity of the eastern Hellenic Subduction Zone between 2002 and 2007 observed by temporary networks, in preparation, 2014.

Chamot-Rooke N., Rangin, C., Le Pichon, X., and Dotmed Working Group: DOTMED - Deep Offshore Tectonics of the Mediterranean: A synthesis of deep marine data in eastern Mediterranean, Mémoire de la Société géologique de France \& American Association of Petroleum Geologists, numéro spécial, 177, 64 pp., 9 maps with cd-rom, 2005.

Chang, S.-J., van der Lee, S., Flanagan, M. P., Bedle, H., Marone, F., Matzel, E. M., Pasyanos, M. E., Rodgers, A. J., Romanowicz, B., and Schmid, C.: Joint inversion for three-dimensional S velocity mantle structure along the Tethyan margin, J. Geophys. Res., 115, B08309, doi:10.1029/2009JB007204, 2010.

Cocard, A., Kahle, H.-G., Peter, Y., Geiger, A., Veis, G., Felekis, S., Paradissis, D., and Billiris, H: New constraints on the rapid crustal motion of the Aegean region: recent results inferred from GPS measurements (1993-1998) across the West Hellenic Arc, Greece, Earth Planet. Sci. Lett., 172, 39-47, 1999.

DeMets, C., Gordon, R. G., Argus, D. F., and Stein, S.: Current plate motions, Geophys. J. Int., 101, 425-478, 1990.
Dercourt, J., Zonenshain, L. P., Ricou, L.-E., Kazmin, V. G., Le Pichon, X., Knipper, A. L., Grandjacquet, C., Sbortshikov, I. M., Geyssant, J., Lepvrier, C., Pechersky, D. H., Boulin, J., Sibuet, J.-C., Savostin, L. A., Sorokhtin, O., Westphal, M., Bazhenov, M. L., Lauer, J. P., Biju-Duval, B.: Geological evolution of the Thetys belt from the Atlantic to the Pamirs since the Lias, Tectonophysics, 123, 241-315, 1986.

Drakatos, G., Karantonis, G., and Stavrakakis, G. N.: P-wave crustal tomography of Greece with use of an accurate two-point ray tracer, Ann. Geofis., 1, 25-36, 1997.

Endrun, B., Meier, T., Bischoff, M., and Harjes, H. P.: Lithospheric structure in the area of Crete constrained by receiver functions and dispersion analysis of Rayleigh phase velocities, Geophys. J. Int., 158, 592-608, doi:10.1111/j.1365-246X.2004.02332.x, 2004.

Endrun, B., Meier, T., Lebedev, S., Bohnhoff, M., Stavrakakis, G., and Harjes, H. P.: S velocity structure and radial anisotropy in the Aegean region from surface wave dispersion, Geophys. J. Int., 174, 593-616, 2008.

Endrun, B., Lebedev, S., Meier, T., Tirel, C., and Friederich, W.: Complex layered deformation within the Aegean crust and mantle revealed by seismic anisotropy, Nat. Geosci., 4, 203-207, doi:10.1038/ngeo1065, 2011.

Engdahl, E. R., Van Der Hilst, R. D., and Buland, R.: Global teleseismic earthquake relocation with improved travel times and procedures for depth relocation, B. Seismol. Soc. Am., 88, 722 743, 1998.

Faccenna, C., Bellier, O., Martinod, J., Piromallo, C., and Regard, V.: Slab detachment beneath eastern Anatolia: A possible cause for the formation of the North Anatolian fault, Earth Planet. Sci Lett., 242, 85-97, 2006.

Forster, M. and Lister, G.: Core-complex-related extension of the Aegean lithosphere initiated at the Eocene-Oligocene transition, J. Geophys. Res., 114, B02401, doi:10.1029/2007JB005382, 2009.

Gealey, W. K.: Plate tectonic evolution of the MediterraneanMiddle East region, Tectonophysics, 155, 285-306, 1988.

Gesret, A., Laigle, M., Diaz, J., Sachpazi, M., Charalampakis, M., and Hirn, A.: Slab top dips resolved by teleseismic converted waves in the Hellenic subduction zone, Geophys. Res. Lett., 38, L20304, doi:10.1029/2011GL048996, 2011.

Hatzfeld, D. and Martin, C.: The Aegean intermediate seismicity defined by ISC data, Earth Planet. Sci. Lett., 113, 267-275, 1992.

Hirn, A., Sachpazi, M., Siliqi, R., McBride, J., Marnelis, F., and Cernobori, L., and the STREAMERS-PROFILES group: A traverse of the Ionian islands front with coincident normal incidence and wide-angle seismics, Tectonophysics, 264, 35-49, doi:10.1016/S0040-1951(96)00116-3, 1996.

Jolivet, L. and Brun, J.-P.: Cenozoic geodynamic evolution of the Aegean, Int. J. Earth Sci., 99, 109-138, doi:10.1007/s00531-0080366-4, 2010.

Kahle, H. G., Cocard, M., Peter, Y., Geiger, A., Reilinger, R., McClusky, S., King, R., Barka, A., and Veis, G.: The GPS strain rate field in the Aegean Sea and western Anatolia, Geophys. Res. Lett., 26, 2513-16, 1999.

Karabulut, H., Paul, A., Ergün, T. A., Hatzfeld, S., Childs, D. M., and Aktar, M.: Long-wavelength undulations of the seismic Moho beneath the strongly stretched Western Anatolia, Geophys J. Int., 194, 450-464, doi:10.1093/gji/ggt100, 2013. 
Karagianni, E. E., Pabagiotopoulos, D. G., Panza, G. F., Suhadolc, P., Papazachos, C. B., Papazachos, B. C., Kirtazi, A., Hatzfeld, D., Makropoulos, K., Priestley, K., and Vuan, A.: Rayleigh wave group velocity tomography in the Aegean area, Tectonophysics, 358, 187-209, 2002.

Kennett, B. L. N. and Engdahl, E. R.: Travel times for global earthquake location and phase identification, Geophys. J. Int., 105, 429-465, doi:10.1111/j.1365-246X.1991.tb06724.x, 1991.

Keskin, M.: Magma generation by slab steepening and breakoff beneath a subduction-accretion complex: an alternative model for collision-related volcanism in eastern Anatolia, Turkey, Geophys. Res. Lett., 30, 8046, doi:10.1029/2003GL018019, 2003.

Kind, R. and Vinnik, L. P.: The upper mantle discontinuities underneath the GRF array from P-to-S converted phases, J. Geophys., 62, 138-147, 1988.

Kind, R., Yuan, X., Saul, J., Nelson, D., Sobolev, S.V., Mechie, J., Zhao, W., Kosarev, G., Ni, J., Achauer, U., and Jiang, M.: Seismic images of crust and upper mantle beneath Tibet: evidence for Eurasian plate subduction, Science, 298, 1219-1221, 2002.

Knapmeyer, M.: Geometry of the Aegean Benioff zones, Annali di Geofisica, 42, 27-38, 1999.

Knapmeyer, M. and Harjes, H. -P.: Imaging crustal discontinuities and the down-going slab beneath western Crete, Geophys. J. Int., 143, 1-21, 2000.

Kosarev, G., Kind, R., Sobolev, S. V., Yuan, X., Hanka, W., and Oreshin, S.: Seismic evidence for a detached Indian lithosphere mantle beneath Tibet, Science, 283, 1306-1309, 1999.

Langston, C. A.: The effect of planar dipping structure on source and receiver responses for constant ray parameter, B. Seismol. Soc. Am., 67, 1029-1050, 1977.

Legendre, C., Meier, T., Lebedev, S., Friederich, W., and ViereckGötte, L.: A shear-wave velocity model for the European upper mantle from automated inversion of seismic shear and surface waveforms, Geophys. J. Int., 191, 282-304, 2012.

Le Pichon, X., Chamot-Rooke, N., and Lallemant, S.: Geodetic determination of the kinematics of central Greece with respect to Europe: Implications for eastern Mediterranean tectonics, J. Geophys. Res., 100, 12675-12690, 1995.

Li, X., Bock, G., Vafidis, A., Kind, R., Harjes, H. -P., Hanka, W., Wylegalla, K., Van der Meijde, M., and Yuan, X.: Receiver function study of the Hellenic subduction zone: imaging crustal thickness variations and the oceanic Moho of the descending African lithosphere, Geophys. J. Int., 155, 733-748, 2003.

Makris, J.: The crust and upper mantle of the Aegean region from deep seismic soundings, Tectonophysics, 46, 269-284, 1978.

Makris, J. and Vees, R.: Crustal structure of the central Aegean Sea and the islands of Evia and Crete, Greece, obtained by refractional seismic experiments, J. Geophys., 42, 330-341, 1977.

Marone, F., Van der Lee, S., and Giardini, D.: Threedimensional upper mantle S-velocity model for the EurasiaAfrica plate boundary region, Geophys. J. Int., 158, 109-130, doi:10.1111/j.1365-246X.2004.02305.x, 2004.

Mascle, J. and Martin, L.: Shallow structure and recent evolution of the Aegean Sea: A synthesis based on continuous reflection profiles, Mar. Geol., 94, 271-299, 1990.

Mascle, J. and Chaumillon, E.: An overview of Mediterranean Ridge collisional accretionary complex as deduced from multichannel seismic data, Geo Mar. Lett., 18, 81-89, doi:10.1007/s003670050056, 1998.
McClusky, S., Balassanian, S., Barka, A., Demir, C., Ergintav, S., Georgiev, I., Gurkan, O., Hamburger, M., Hurst, K., Kahle, H., Kastens, K., Kekelidze G., King, R., Kotzev, V., Lenk, O., Mahmoud, S., Mishin, A., Nadariya, M., Ouzounis, A., Paradissis, D., Peter, Y., Prilepin, M., Reilinger, R., Sanli, I., Seeger, H., Tealeb, A., Toksöz, M. N., Veis, G.: Global Positioning System constrains on plate kinematics and dynamics in the eastern Mediterranean and Caucasus, J. Geophys. Res., 105, 5695-5719, 2000.

McKenzie, D.: Active tectonics of the Mediterranean region, Geophys. J. Roy. Astr. S., 30, 109-185, 1972.

McKenzie, D.: Active tectonics of the Alpine-Himalayan belt: the Aegean Sea and surrounding regions, Geophys. J. Roy. Astr. S., 55, 217-254, 1978.

Meier, T., Dietrich, K., Stöckhert, B., and Harjes, H. P.: 1dimensional models of the shear-wave velocity for the eastern Mediterranean obtained from the inversion of Rayleigh wave phase velocities and tectonic implications, Geophys. J. Int., 156, 45-58, 2004.

Meier, T., Becker, D., Endrun, B., Rische, M., Bohnhoff, M., Stöckhert, B., and Harjes, H. P.: A model for the Hellenic subduction zone in the area of Crete based on seismological investigations, in: The Geodynamics of the Aegean and Anatolia, edited by: Taymaz, T., Yilmaz, Y., and Dilek, Y., Geol. Soc. Spec. Publ., 291, 183-199, 2007.

Owens, T. J., Zandt, G., and Taylor, S. R.: Seismic evidence for an ancient rift beneath the Cumberland Plateau, Tennessee: A detailed analysis of broadband teleseismic P waveforms, J. Geophys. Res., 89, 7783-7795, 1984.

Özbakir, A. D., Sengör, A. M. C., Wortel, M. J. R., and Govers, R.: The Pliny-Strabo trench region: A large shear zone resulting from slab tearing, Earth Planet. Sci. Lett., 375, 188-195, 2013.

Papazachos, B. C. and Comninakis, P. E.: Geophysical and tectonic features of the Aegean arc, J. Geophys. Res., 76, 8517-8533, 1971.

Papazachos, B. C., Karakostas, V. G., Papazachos, C. B., and Scordilis, E. M.: The geometry of the Wadati-Benioff zone and lithospheric kinematics in the Hellenic arc, Tectonophysics, 319, 275-300, 2000.

Papazachos, C. and Nolet, G.: P and S deep velocity structure of the Hellenic area obtained by robust nonlinear inversion of travel times, J. Geophys. Res., 102, 8349-8367, 1997.

Pearce, F. D., Rondenay, S., Schapazi, M., Charalampakis, M., and Royden, L. H.: Seismic investigation of the transition from continental to oceanic subduction along the western Hellenic Subduction Zone, J. Geophys. Res., 117, B07306, doi:10.1029/2011JB009023, 2012.

Piromallo, C. and Morelli, A.: P wave tomography of the mantle under the Alpine-Mediterranean area, J. Geophys. Res., 108, 2065, doi:10.1029/2002JB001757, 2003.

Reilinger, R., McClusky, S., Paradissis, D., Ergintav, S., and Vernant, P.: Geodetic constraints on the tectonic evolution of the Aegean region and strain accumulation along the Hellenic subduction zone, Tectonophysics, 488, 22-30, doi:10.1016/j.tecto.2009.05.027, 2010.

Sachpazi, M., Hirn, A., Clément, C., Haslinger, F., Laigle, M., Kissling, E., Charvis, P., Hello, Y., Lépine, J.-C., Sapin, M., and Ansorge, J.: Western Hellenic subduction and Cephalonia Trans- 
form: local earthquakes and plate transport and strain, Tectonophysics, 319, 301-319, 2000.

Schmid, C., Van Der Lee, S., and Giardini, D.: Delay times and shear wave splitting in the Mediterranean region, Geophys. J. Int., 159, 275-290, 2004.

Snopek, K. and Casten, U.: 3GRAINS: 3-D Gravity Interpretation Software and its application to density modeling of the Hellenic subduction zone, Comput. Geosci., 32, 592-603, doi:10.1016/j.cageo.2005.08.008, 2006.

Sodoudi, F., Kind, R., Hatzfeld, D., Priestley, K., Hanka, W., Wylegalla, K., Stavrakakis, G., Vafidis, A., Harjes, H. P., and Bohnhoff, M.: Lithospheric structure of the Aegean obtained from $\mathrm{P}$ and S receiver functions, J. Geophys. Res., 111, B12307, doi:10.1029/2005JB003932, 2006.

Sodoudi, F., Yuan, X., Asch, G., and Kind, R.: High-resolution image of the geometry and thickness of the subducting Nazca lithosphere beneath northern Chile, J. Geophys. Res., 116, B04302, doi:10.1029/2010JB007829, 2011.

Spakman, W., Wortel, M. J. R., and Vlaar N. S.: The Hellenic subduction zone: A tomographic image and its geodynamical implications, Geophys. Res. Lett., 15, 60-63, 1988.

Spakman, W., Van der Lee, S., and Van der Hilst R. D.: Travel time tomography of the European-Mediterranean mantle down to $1400 \mathrm{~km}$, Phys. Earth Planet. In., 79, 3-73, 1993.

Stampfli, G. M. and Borel, G. D.: The transmed transect in space and time: Constraints on the paleotectonic evolution of the mediterranean domain, in: The TRANSMED Atlas: the Mediterranean Region from Crust to Mantle, edited by: Cavazza, W., Roure, F., Spakman, W., Stampfli, G. M., and Ziegler, 53-80, Springer Verlag, Berlin, 2004.

Suckale, J., Rondenay, S., Sachpazi, M., Charalampakis, M., Hosa, A., and Royden, L. H.: High-resolution seismic imaging of the western Hellenic subduction zone using teleseismic scattered waves, Geophys. J. Int., 178, 775-791, 2009.

Thomson, S.N., Stöckhert, N., and Brix, M.R.: Thermochronology of the high-pressure metamorphic rocks of Crete, Greece: implications for the speed of tectonic processes, Geology, 26, 259262,1998
Tirel, C., Gueydan, F., Tiberi, C., and Brun, J. -P.: Aegean crustal thickness inferred from gravity inversion, Geodynamical implications, Earth Planet. Sci. Lett., 228, 267-280, doi:10.1016/j.eps1.2004.10.023, 2004.

Vanacore, E. A., Taymaz, T., and Saygin, E.: Moho structure of the Anatolian Plate from receiver function analysis, Geophys. J. Int., 193, 329-337, doi:10.1093/gji/ggs107, 2013.

Van Hinsbergen, D. J. J., Hafkenscheid, E., Spakman, W., Meulenkamp, J. E., and Wortel, R.: Nappe stacking resulting from subduction of oceanic and continental lithosphere below Greece, Geology, 33, 325-328, 2005.

Wagner, L. S., Beck, S., and Zandt, G.: Upper mantle structure in the south central Chilean subduction zone $\left(30^{\circ}\right.$ to $\left.36^{\circ} \mathrm{S}\right)$, J. Geophys. Res., 110, B01308, doi:10.1029/2004JB003238, 2005.

Wortel, R. and Spakman, W.: Subduction and slab detachment in the Mediterranean-Carpathian region, Science, 290, 1910-1917, 2000.

Yuan X., Ni, J., Kind, R., Mechie, J., and Sandvol, E.: Lithospheric and upper mantle structure of southern Tibet from a seismological passive source experiment, J. Geophys. Res., 102, 491-500, 1997.

Zandt, G., Velasco, A. A., and Beck, S. L.: Composition and thickness of the southern Altiplano crust, Bolivia, Geology, 22, 1003 1006, 1994.

Zheng, Y. and Lay, T.: Low Vp/Vs ratios in the crust and upper mantle beneath the Sea of Okhotsk inferred from teleseismic pMP, sMP, and sMS underside reflections from the Moho, J. Geophys. Res., 111, B01305, doi:10.1029/2005JB003724, 2006.

Zhu, L. and Kanamori, H.: Moho depth variation in southern California from teleseismic receiver functions, J. Geophys. Res., 105, 2890-2969, 2000.

Zhu, L., Mitchell, B. J., Akyol, N., Cemen, I., and Kekovali, K.: Crustal thickness variations in the Aegean region and implications for the extension of continental crust, J. Geophys. Res., 111, B01301, doi:10.1029/2005JB003770, 2006. 